\title{
Türkiye'deki Suriyeli Nüfusun Sosyal ve Mekansal Görünümü: Adana Suriyeliler Caddesi Örneği
}

\author{
The Social and Spatial View of Syrian Population in Turkey: \\ A Case Study of Adana Syrians Street
}

\section{Suat KOLUKIRIK * Gökhan DURU **}

\begin{abstract}
$\ddot{O}_{z}:$ Göç gruplarının etkilerini ve etkileşimini konu edinen akademik çalışmalarda göçün ortaya çıkardığı toplumsal değişme biçimleri göç sürecini bir yönetim sorunu olarak görmekte ve tartışmaktadır. Zira göçle gelen nüfusun sosyal ve mekansal sorunları, sosyal içerme ve göç politikalarına ihtiyaç duymakta ve toplumsal sistemin geleceğini belirlemede başat bir rol oynamaktadır. Özellikle göç gruplarının külttürel farklılıklarıyla birlikte içinde yaşadığı yeni toplumun bir parçası oluşu ve sosyal sisteme katılımda eşit hak ve imkanlara ulaşabilme kabiliyeti göçün sonuçlarını belirleyen faktördür. Bu perspektiften hareketle çalışmada, düzensiz uluslararası göç örneği olarak Adana iline yerleşen Suriyeli göçmen nüfusun sosyal ve mekansal görünümü Suriyeliler Caddesi örnekleminde; bütünleşme, farklılaşma, mekansallaşma ve aidiyet kavramlarıyla irdelenmeye çalışılmış ve değerlendirilmiştir. Araştırmada karma yöntem tercih edilerek anket, mülakat ve gözlem teknikleri kullanılmış, elde edilen nicel ve nitel veriler çalışmanın sorgu alanı içerisinde tasnif edilmiş, tablolaştırılmış ve analiz edilmiştir. Veri toplama süreci 02-30 Aralık 2019 tarihleri arasında gerçekleştirilmiş, toplam 354 Suriyeli göçmene anket uygulanmış ve görüşmelerde istisnasız anadili Arapça olan tercümanların katılımları ve destekleriyle sağlanmıştır. Suriyeli göç gruplarının mekansal dağılımında; sosyo-ekonomik durum, akrabalık, tanıdıklık, din, dil ve mekansal algı faktörlerinin belirleyici olduğu ve sosyal uyum sorunlarının devam ettiği bulgulanmıştır.
\end{abstract}

Anahtar sözcükler: Düzensiz göç, Suriyeliler, Mekansallaşma, Sosyal Uyum, Adana

\begin{abstract}
In the academic studies that treat the impacts of, and the interaction between immigration groups, the types of social change that result from immigration view and discuss immigration process as a management problem. The social and spatial issues of the population that emerge with immigration are in need of social inclusion and immigration policies, and they play a crucial role in determining the future of the social system. Immigration groups' ability to become a part of, along with their cultural differences, the new society they live in, and to gain equal rights and opportunities to participate in the social system is the factor that determines the results of immigration. From this perspective, in this study, the social and spatial view in the case of Syrians Street, the Syrian immigrant population that settled in Adana province as an example of irregular international immigration has been addressed and evaluated in the context of integration, differentiation, spatialization, and belonging. By using the mixed method, the study has been conducted using survey, interview, and observation techniques; obtained quantitative and qualitative data have been classified, tabulated, and analyzed within the scope of the study. The data collection process has been conducted between the dates of 02-30 December 2019; a total of 354 Syrian immigrants have been surveyed, and participation and support of interpreters, whose native language is Arabic, have been provided during the interviews with no exception. It has been discovered that in the spatial distribution of Syrian immigrationgroups; factors such as socio-economic condition, affinity, acquaintance, religion, language, and spatial perception are determinants, and social adaptation issues keep continuing.
\end{abstract}

Keywords: Irregular Immigration, Syrians, Spatialization, Social Adaptation, Adana

\footnotetext{
* Prof. Dr., Akdeniz Üniversitesi, Edebiyat Fakültesi, Sosyoloji Bölümü, Antalya. suatkolukirik@akdeniz.edu.tr, https://orcid.org/0000-0003-0399-666X

** Uzman Sosyolog; Yetimler Derneği, Adana, bilgi@gokhanduru.com, https://orcid.org/0000-0002-5633-8444
} 


\section{Giriş}

Uluslararası düzensiz göç hareketlerinin ortaya çıkardığı sosyal ve mekansal bütünleşme problemleri, günümüz dünyasında çoğu batılı ve gelişmekte olan ülkenin arzu etmediği bir sonuç ve tartışma alanıdır. Farklı kültürel özelliklere sahip göç gruplarının değişik nedenler ve beklentilerle göç etmesi şehir ve ülkelerin mevcut sosyal yapılarını değişime uğratmakta ve alt yapı imkanlarının sınırlılığı istenmeyen bazı görünümlere yol açabilmektedir. Diğer bir ifadeyle yoğun oranlı düzensiz uluslararası göç hareketleri yeni yerleşim yeri ve kent alanlarında fiziki altyapı ve üst yapı ihtiyacını ortaya çıkarmakta ve başta barınma olmak üzere nitelikli kamusal ve insani hizmetlere ulaşımı engelleyebilmektedir. Nitekim mekansal anlamda, kamusal hizmetlerin dağılımı kentin bütününü etkileyen bir özelliktir ve ortak kullanım alanlarının zenginliği toplumsal yaşama katılımı desteklemektedir.

Uluslararası düzensiz göç gruplarının barınma, istihdam ve eğitim firsatlarına ulaşımı kadar, kadın ve çocuk sağlığı, aile planlaması, bulaşıcı hastalıklar ve engelli bireylerin bakımı gibi konular temel ihtiyaç bölümlerini oluşturmakta ve çözülmesi gereken alanlar olarak kalabilmektedir. Bu manada düzensiz göç gruplarının sosyal sisteme katılımında sosyal içerme politikaları ve sosyal uyum programları önemli destekleyiciler olarak rol oynamakta ve göçün etki alanı ve süresini belirlemektedir. Öte taraftan sosyal sisteme katılım imkanı sınırlı olan kesimlerin ekonomik, sosyal ve kültürel olanaklara erişiminin kolaylaştırılması sosyal gelişmişlik açısından bir ihtiyaç ve gereklilik olarak değerlendirilmektedir. Ayrıca sosyal sermaye açısından bireylerin birbirlerine ve sosyal kurumlara karşı duymuş olduğu güven düzeyinin yüksekliği, işbirliği ve başarıyı artırıcı bir etkendir. Kadın, çocuk, yaşlı ve bakıma muhtaç nüfusun ihtiyaçlarının çözümüne ilişkin yürütülen uygulamalar büyük oranlı göç süreçlerinin massedilmesinde önemli bir ayrıntıdır. Düzensiz uluslararası göçün ortaya çıkardığ leşme sorununun diğer bir nedeni de ekonomiktir ve yoksulluk kaynaklı şekillenmektedir. Bu noktada çalışabilir yaşta olan nüfusun niteliğinin artırılması, kayıt dış1 istihdamın önlenmesi, çalışma ortamlarının iyileştirilmesi ve iş güvenliğinin sağlanması gibi düzenlemeler göç gruplarının sosyal uyumunu kolaylaştırıcı uygulamalardır.

Düzensiz göç gruplarının mekan ya da yerleşim yeri tercihinde farklı etkenler rol oynamakla birlikte çoğunlukla dayanışma ihtiyacı ve aynı yazgıyı paylaşıyor olma düşüncesi ön plana çıkmaktadır. Bununla birlikte göçmenlerin bir arada bulunma ya da mekansallaşma süreçleri bazı fiziki sınırlılık ve yasal izinlerle çerçevelenmiş durumdadır. Örneğin Adana'daki Suriyeli göçmen gruplar için ayrılan yerleşim alanları başlangıçta çadırkent ya da geçici barınma merkezleri olarak planlanmış iken artan göçmen sayısının miktarı karşısında gelen göçmen nüfus, başka bölge ve mahallere dağılmış ve taşmış bulunmaktadır. Göçmen nüfusunun büyüklüğü ve miktarı iş piyasası, konut, altyapı, tüketim ve kültürel yaşam alanı gibi ihtiyaçları belirginleştirmiş ve kent sosyal dokusu içerisinde ve özellikle Suriyeliler Caddesi olarak anılan Mirzaçelebi Sokak ve yakın çevresindeki mahalleler etrafında bir göçmen yerleşimi ve kümelenmesi ortaya çıkarmıştır. Bu görünüm ve örneklem alanının kapsamı içerisinde çalışmamızda Suriyeli göçmen nüfusun mekan tercihi, mekanı kullanma biçimleri, yerleşim yeri oluşturmadaki beklentileri ve mekansal algıları; demografik özellikler, ekonomik durum, deneyimler, yaşam pratikleri, aidiyet ve kente uyum parametreleri üzerinden irdelenmiştir ve tartış1lmıştır.

\section{Düzensiz Göç Mekansal Yoğunlaşma ve Ayrışma}

Göçmenlerin göç ettikleri ülkelerde özellikle bazı şehir, bölge ve mahallelerde yoğunlaşmaları literatürde mekansal yoğunlaşma, ayrışma, kümelenme ve coğrafi yoğunlaşma gibi kavramlarla ifade edilmektedir. Bu makalede sıklıkla kullandığımız mekansal ayrışma kavramı da belirli kültürel benzerliklere sahip olan grupların mekansal yoğunlaşmasını ve diğer bölgelerde daha az bulunmasını ve farklılaşmayı ifade etmektedir (Van Kempen \& Özüekren 1998, 1632). Diğer 
bir tanımlamayla mekansal ayrışma kavramı, belirli bölgelerdeki yoğunlaşmaya işaret etmekte ve mekansal olarak belirli alanlarda toplanmış nüfusun yerel halktan ayrıştığına vurgu yapmaktadır (Hugo 2011, 18). Nitekim Amerika Birleşik Devletleri'nde göçmenlerin etnik grupların bulunduğu şehirlerde yoğunlaşmayı tercih etmesi (Bartel 1989); Kaliforniya, New York, Teksas, Florida, New Jersey ve Illinois eyaletleri ile (Chiswick \& Miller 2004, 3) ülkemizde İstanbul, Ankara, İzmir, Bursa gibi metropoller ve Ege, Akdeniz kıyılarında görülen nüfus hareketlilikleri mekansal yoğunlaşma (Yakar \& Temurçin 2013, 220) olgusunu yansıtan örneklerden sadece birkaçıdır.

Mekanın konumu, içinde barındırdığı sosyo-ekonomik, politik imkanları ve orada yaşayanların özellikleri göçmenlerin mekansal tercihini doğrudan etkileyen faktörlerdir. Gerçekte çeşitli sosyo-ekonomik, kültürel, coğrafi ve politik özelliklerin taşıyıcılı̆̆ını yapan ve temsilcisi olan mekan, göçmenler için göç edilen yer tercihinde bu özellikleri temelinde önem kazanmakta ve anlam bulmaktadır. Göç eden grubun niteliği, göç etme sebepleri ve ihtiyaçları doğrultusunda mekanlar, göçmenler tarafından çeşitli biçimlerde yoğunlaşma alanları görülmekte ve değer kazanmaktadır. Diğer bir ifadeyle benzer sosyo-kültürel ve dini özelliklere sahip olan gruplarla ilişki kurabilme imkanı sağlayan mekanlar, bireylerin davranışlarını etkileyen ve biçimlendiren alanlardır (Hugo 2011, 5). Bunun dışında mekan tercihinde çeşitli biçimlerde birbirine bağlı olan tüm etkenler, göçmenlerin benzer dil, din, etnik köken ve kültürel geleneğe sahip olup olmama koşuluna bağlı olarak şekillenmiş özel bir alandır.

\section{Mekan Algısı ve Tercihinin Dinamikleri}

Sosyal inşa sürecinin bir parçası olan mekan, insan izlerini taşımakta ve her toplumsal faaliyet biçimi kendi mekanını tanımlamaktadır (Güleç Solak 2017, 35). Bir diğer ifadeyle mekan, toplumsal bir ürün olarak karşımıza çıkmakta, mekanın kullanım biçimleri mekanın kendisini şekillendirmekte ve mekana ilişkin bir kimlik yaratmaktadır (Lefebvre 2014, 24). Toplumsal ile mekansal olanın iç içeliğine yapılan bu vurgu, toplumsal süreçler ile mekansal biçimlerin, birbirlerinden ayırt edilemeyecek olan ilişkisine karşıllk gelmekte ve tasavvur edilmektir (Harvey 2013, 27-92).

Ait olduğu toplumsal ve fiziksel bağlarından kopan ve gittiği bölgeye yabancı olan göçmenler için benzer kökene sahip olan kişilere ulaşabilme ve onlara yakın olabilme durumu oldukça önemli bir kriterdir. Bu bağlar göçmenlerin bildik ve tanıdık olan ile kendini güvende hissetmelerini sağlamakta ve göç ettikleri yere uyum sağlamada destek mekanizması işlevi görmektedir. Zira geleneksel bağlarından koparılan, kendilerini köksüz hisseden, yabancı bir yerde varlık mücadelesi veren ve bir yerlere ait olmak ihtiyacı hisseden bireyler için 'aynı yerden gelmek' büyük önem taşımakta ve 'biz' algısı bir tutunma kaynağı işlevi yüklenmektedir (Köse 2008, 225226). Tüm bunların doğal bir sonucu olarak göçmenler, benzer kökene sahip bireylerin yaşadığ 1 alanlarda yaşama isteği göstermekte ve bu durum literatürde etnik yoğunlaşma ve etnik yerleşim bölgeleri sınıflandırılmasıyla adlandırılmaktadır (Chiswick \& Miller 2004, 1).

Türkiye'ye yönelik gerçekleştirilen ulus ötesi göçlerde akrabalık ve tanıdıklık ilişkilerinin ve benzer kökene sahip olmanın kişilerin mekan tercihleri üzerinde önemli belirleyiciler olduğunu gösteren farklı çalışmalara da rastlamak mümkündür. Örneğin Balkanlardan gelen göçmenler, mekan ve yerleşim yeri tercihinde yakınlarının bulunduğu şehirlere göç etme yönünde eğilim göstermişlerdir (Kolukırık 2006; Çetin 2010; Ünal 2012). Benzer bir biçimde Türkiye'ye coğrafi sınır yakınlığı dışında Hatay'ın din ve mezhep farklılığı temelinde şekillenen yapısı, Suriyeli göçmenlerin yerleşim yeri tercihinde etkili olmuş benzerlik, tanıdıklık ve akrabalık ilişkileri göç sürecini kolaylaştırmıştır (Harunoğulları \& Cengiz 2014, 314; Kolukırık \& Özcan 2019, 204). Bunun dışında yabancı uyruklu göçmelerin yoğun oranda yaşadığ 1 şehirler ile daha fazla yabancı göçü alan şehirlerarasında bir paralellik olduğuna ilişkin veriler akademik 
çalışmalara yansımış durumdadır (Yakar \& Temurçin 2013, 224).

Günümüzde kamp dışında kalan Suriyeli göçmenlerin en yoğun şekilde yaşadığı şehirler ise İstanbul, Gaziantep, Hatay, Şanlıurfa ve Adana'dır (İçişleri Bakanlığı Göç İdaresi Genel Müdürlügü̈, 2020). Bu manada yerel halkın göç eden Suriyeliler ile akrabalık, aşiret ilişkileri, dilsel ve kültürel ortaklıklarının olması bölgesel yoğunlaşmayı anlaşılır kılan önemli bir unsurdur (Lordoğlu \& Aslan 2016, 790). Türkiye'deki coğrafi ve kültürel yakınlık kaynaklı etnik yoğunlaşmalar başlangıçta Doğu ve Güneydoğu Anadolu illerinden Van'a yapılmış iken (Deniz 2009, 198) Trabzon, Rize, Artvin ve Ardahan illeri Kafkasya ve Rusya'dan gelen göçmenlerin fazla nüfuslarıyla öne çıkmaktadır (Yakar \& Temurçin 2013, 225). İstanbul dışındaki yerleşimlerde ise göçmen gruplarının turizm merkezlerinde yoğunlaştığını gösteren güçlü eğilimler görülmektedir (Südaş 2005, 58; Deniz \& Özgür 2010, 16-17; Yakar 2013, 512; Yakar \& Temurçin 2013, 226).

Dil yeterliliği olmayan göçmenlerin, istihdama dahil olabilmek adına çoğunlukla kendi etnik grubunun yoğun yaşadığı bölgeleri tercih etmesi bilindik bir durumdur (Maani 2016, 5). Yeni Zelanda'da İngilizce konuşulmayan ülkelerden göç eden kişilerin yerleşim kararlarında etnik bağlantılar, İngilizce konuşulan ülkelerden göç eden kişilere oranla daha etkin olduğu bulgulanmıştır (Wang \& Maani, 2014b, 92). Benzer bir şekilde Amerika Birleşik Devletleri'nde göçmenlerin anadilleri, yer tercihlerinde belirleyiciliğe bir özelliğe sahiptir (Chiswick \& Miller 2004). Bu anlamda dilsel ortaklık, ülkemizde Suriyelilerin en yoğun nüfusa sahip oldukları şehirleri tercih etmelerinde belirleyici bir etkendir (Lordoğlu \& Aslan 2016, 790).

Göçmenlerin ulaşabilecekleri iş imkanları, sahip oldukları sosyo-ekonomik statüleri ve ucuz mülkiyet ve kaynaklara erişim gibi çeşitli durumların da mekansal tercihi belirleyen süreçler olduğu görülmektedir. Nitekim göçmenler, dilsel, kültürel farklılıkları ve yerel iş piyasasından uzak olmaları sebebiyle göç ettikleri bölgenin ekonomisine dahil olma konusunda çeşitli sıkıntılar yaşamaktadırlar. Bu süreçte ekonomik ve sosyal ağların benzer sosyo-kültürel öğelere dayandığ1 yoğunlaşma bölgelerinde etnik sermaye önemli bir çözüm aracı görülmektedir (Maani 2016, 1). Etnik sermaye kavramı Borjas'1n $(1992,127)$ etnik çevrenin sahip olduğu birikim ve yeteneklerin, nesillere aktarılma sürecini ifade etmek için kullandığı bir kavramdır. Daha geniş anlamda ise etnik yoğunlaşmayı ve göçmenlerin etnik bağlantılarını ifade eden etnik sermaye, bireylere belirli bir etnik gruba ait olmaktan ötürü çeşitli avantajlar sağlayabilmektedir (Wang \& Maani 2014a, 3). Yeni Zelanda örneğinde güçlü etnik yerleşim bölgelerinin kişilerin iş piyasasına dahil olmaları üzerinde pozitif bir etkisi olduğu ifade edilmiştir (Wang \& Maani 2014b, 107). Benzer şekilde Türkiye'deki göçmen etnik gruplar ve hemşehrilerle kurulan bağlar, iş bulma sürecini kolaylaştıran tampon bir mekanizma olarak tanımlanmıştır (Kurtoğlu, 2005, 18; Çetin 2010, 73; Aygül 2018, 204).

Göçmenlerin mevcut ekonomik statülerine, alım güçlerine ve iş sahasına göre mekansal tercihlerde bulunmaları ve göçmenlerinin yerleşim yeri tercihlerinde çeşitli ekonomik etkenlerin belirleyici olduğunu da belirtmek gerekmektedir (Kolukırık 2006; Çetin 2010; Harunoğulları \& Cengiz 2014). Daha yüksek ekonomik getiriye sahip olan Suriyelilerin Hatay kentinin daha zengin ve orta sınıfların yaşadığı mahalle ve bölgelerde yaşamayı tercih ettikleri görülürken düzenli bir gelir seviyesi olmayan Suriyelilerin ise daha düşük ekonomik statüye sahip olan mahallelerde yaşadıkları bilinmektedir (Harunoğulları \& Cengiz 2014). Ayrıca ilk dönemlerinde Suriyeli göçmenlerin, kamplarda yaşamayı tercih etme sebeplerinin başında ekonomik nedenlerin geldiği, akademik çalışmalar ve kamusal raporlarda yer almıştır (AFAD 2013, 46-47).

Göçmenlerin kentsel ve kırsal mekanlar arasında yaptıkları tercihler, küreselleşen dünyada yeni bir eğilimin göstergesi olarak da kendisini hissettirmektedir. Dahası yer değişimininin, yeni yaklaşımları gerektiren ve giderek önemli bir kentsel sorun haline gelmeye başladığı tartışıl- 
maya başlanmıştır (International Rescue Committee Urban Refugees, 2012). Örneğin 1990 sayımlarında Amerika Birleşik Devletleri'nde göçmenler, yerli halka kıyasla daha fazla kentsel mekanlarda yaşama eğilimi göstermişlerdir. Göçmelerin \% 94'ü kentsel alanlarda yaşarken, 5 yaş üstü yerli halkın ise \%74'ünün kentsel mekanlarda yaşadığı ortaya çıkmıştır (Chiswick \& Miller 2004, 6). Avustralya'da özellikle savaş sonrası dönemde nüfus genel olarak kentsel alanlarda yaşama yönünde güçlü bir eğilim göstermiş ancak bu eğilimin, özellikle göçmeler arasında daha belirgin bir şekilde olduğu bulgulanmıştır (Hugo 2011, 11). Almanya örnekleminde de göçmenler yoğun bir şekilde kentlerde yaşamayı tercih etmektedirler (Schönwälder \& Söhn 2009 , 1443). Türk uyruklu ülkeye geri dönüş yapan göçmenler de dahil olmak üzere tüm göçmenlerin temelde ve öncelikle kentsel alanları tercih ettiği artık bilindik bir durumdur (Yakar \& Temurçin 2013, 223-224).

\section{Araştırmanın Yöntem ve Tekniği}

Bir alan araştırması olarak tasarlanan bu çalışma, düzensiz uluslararası göç ile Adana'ya gelen nüfusun sosyal ve mekansal görünümünü sosyolojik açıdan analiz etmeyi hedeflemektedir. Araştırmanın sorgu alanı çerçevesinde karma yöntem tercih edilerek nicel ve nitel teknikler birlikte kullanılmış (Leech \& Onwuegbuzie 2009) anket, mülakat ve görüşmeler anlamacı bir yaklaşımla gerçekleştirilmiş ve tüm veriler yerinde ve örneklem alanından toplanmıştır. Araştırmanın kapsamı bağlamında, İçişleri Bakanlığ 1 Göç İdaresi Genel Müdürlüğü’nün Aralık-2019 verilerine göre Adana; İstanbul, Gaziantep, Hatay ve Şanlıurfa illerinden sonra en fazla Suriyeli göçmen nüfusunu barındıran 5. il konumunda yer almıştır. Bunun dışında TÜIKK Aralık 2019 yılı verilerine göre, Adana'nın nüfusu 2.237.940 olup il nüfusunun yaklaşık \% 40'ını Seyhan ilçesi oluşturmaktadır. Adana'da resmi olarak kayıtlı 243.101 Suriyeli göçmen bulunmakta Seyhan, Yüreğir ve Sarıçam yoğun orandaki bir nüfusa ev sahipliği yapan ilçeler olarak sıralanmaktadır. Merkez ilçe konumundaki bu üç ilçe arasında, genel nüfus yoğunluğuyla paralel olarak yaklaşı 100 bin Suriyeli göçmenin Seyhan ilçesinde yaşadığı öngörülmektedir.

Seyhan ilçesi örnekleminde, yerli halk tarafından da Suriyeliler Caddesi olarak bilinen Mirzaçelebi Sokak ve yakın çevresindeki mahalleler göçmen nüfusunun yoğunlaştığı kent içi özel bir alan niteliğiyle tanınmakta ve bilinmektedir. Suriyeliler Caddesinin örneklem alanı olarak belirlenmesinde, araştırmacıların örneklem alanına olan yakınlığı ve araştırmanın maliyet durumu göz önünde bulundurulmuş olsa da, esas önemli olan husus Suriyeli göçmenlerin en yoğun yaşadığı bölge ve mahalleleri kapsıyor oluşudur. Betimsel olarak ise Suriyeliler Caddesi, yaklaşık 2 kilometre uzunluğuyla Suriye'ye özgü mal ve ürünlerin satıldığ 1 , sıralı ve karşılıklı dükkanları ile yerelden farklılaşmış, gün boyu kalabalık, hareketli ve göçmenlerin biz duygusunu besleyen kültürel ve ekonomik bir aidiyet ve buluşma alanıdır. Mirzaçelebi Mahallesi ile birlikte Kocavezir, Yeşilyuva, Dumlupınar, Gülpınar ve Meydan mahalleleri yakın mekansal sınırları ve geçişkenliği nedeniyle örnekleme dahil edilmiş, sahip olduğu merkezi ve çarşı olma konumu nedeniyle araştırma Suriyeliler Caddesi üzerinden tasarlanmış ve adlandırılmıştır.

Araştırma deseni içerisinde tesadüfi örneklemle \% 95 güven aralığ1 ve (+-5) hata payı ile 383 Suriyeli göçmene ulaşmak hedeflenmiş, görüşme ortamının uygunsuzluğu ve görüşmenin yarım bırakılması gibi muhtelif sebeplerle 354 Suriyeliye anket uygulanabilmiştir. Görüşülenlere 51 sorudan oluşan özel bir anket formu uygulanmış ve formda yer alan sorular 5 ayrı bölümde sınıflandırılmıştır. Veri toplama işlemi 02-30 Aralık 2019 tarihleri arasında gerçekleştirilmiş ve tüm görüşmeler, istisnasız olarak anadili Arapça olan yerel tercümanların katılımları ve destekleriyle sağlanmıştır. Her bir anket yaklaşık 25-30 dakika arasında tamamlanmış ve günde ortalama 15 kişiye ulaşılabilmiştir. Anket uygulaması her haneden bir kişiyi temsil edecek bir dağılımla yürütülmüş, görüşmeler yoğun olarak öğleden sonraki zaman diliminde ve akşam saatlerinde aile için uygun bir ortamda, evlerde yapılmıştır. 


\section{GEÇiCi KORUMA KAPSAMINDA BULUNAN SURIYELILERIN ILK 10 iLE GÖRE DAĞILIMI}

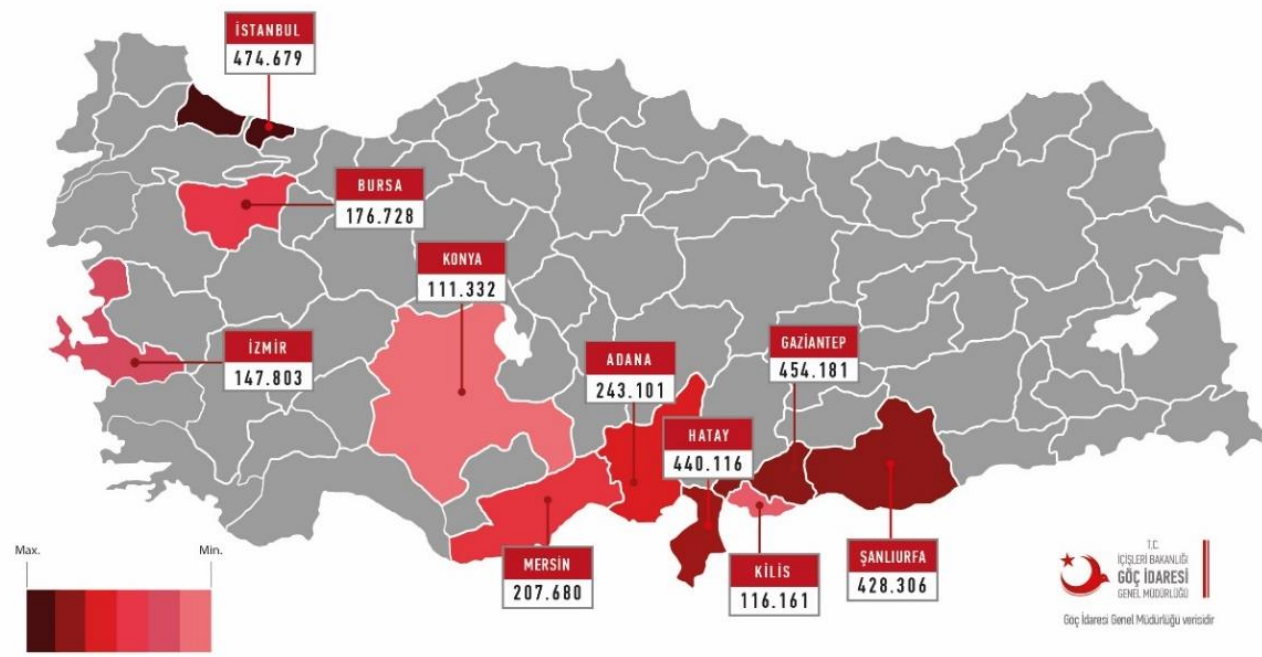

Fig. 1. Kaynak: İçişleri Bakanlığg Göç İdaresi Genel Müdürlüğü, https://www.goc.gov.tr/gecici-koruma5638 Son erişim: 01.01.2020

Örneklem alanından toplanan nicel verilerin bilgisayara aktarılabilmesi için veri kodlama işlemi yapılmış ve numerik olarak kodlanan verilerin SPSS programı aracılığıyla frekans dağılımları, düz ve çapraz tabloları oluşturulmuş, gözlem ve mülakat verilerinin de eklenmesiyle sonuç raporu yazılmıştır.

\section{Araştırmanın Bulguları ve Veriler}

\section{Demografik Özellikler}

Görüşülenlerin demografik dağılımı; yaş, cinsiyet, eğitim düzeyi ve medeni durum özellikleri bağlamında irdelenmiş, 174'ü kadın $(\% 49,2)$ ve 180'i $(\% 50,8)$ erkek olmak üzere toplam 354 katılımcı ile görüşme gerçekleştirilmiştir. Araştırmaya katılanlar arasında 26-35 yaş grubu 99 kişi ile en fazla görüşülen yaş aralığını oluşturmuş ve tüm görüşmelerin \%28,0'ini teşkil etmiştir. $18-25$ yaş grubunda 78 kişi $(\% 22,0)$ ve $36-45$ yaş grubunda 75 kişi $(\% 21,2)$ yer almıştır. Bu yaş aralıkları, tüm görüşülenlerin \%71,2'sini oluşturmuş ve genel anlamda çalışabilir, üretebilir ve dinamik yaş gurubunu temsil etmiştir. Diğer yaş gruplarında ise sırasılyla 46-55 yaş aralığında 66 kişi $(\% 18,6), 56-65$ yaş aralığında 30 kişi $(\% 8,5)$ ve 66 yaş ve üzerinde ise 6 kişi $(\% 1,7)$ bulunmaktadır.

Eğitim düzeyi özelliklerine göre göçmenlerin \%37,0'1 ilkokul mezunudur. Ancak hiçbir mezuniyeti olmayıp okuma-yazma bilmeyen \% 23,4'lük oran bu bölümdeki en çarpıcı istatistiktir. Nitekim yaklaşık 'her dört-beş kişiden birisi okuma-yazma bilmiyor'” diyebileceğimiz bu veri, Suriye'den Türkiye'ye göç eden nüfusun eğitim durumunu anlama noktasında son derece önemlidir. Öte taraftan diğer seçenekler içerisinde eğitim düzeyi; okur-yazar olan 61 kişi $(\% 17,2)$, ilkokul terk 9 kişi $(\% 2,5)$, ortaokul mezunu 21 kişi $(\% 5,9)$, ortaokul terk 12 kişi $(\% 3,4)$, lise mezunu 19 kişi $(\% 5,4)$, lise terk 10 kişi $(\% 2,8)$, üniversite mezunu 5 kişi $(\% 1,4)$, üniversite terk 2 kişi $(\% 0,6)$ ve yüksek lisans/doktora mezunu 1 kişi $(\% 0,3)$ yer almıştır. 
Tablo 1. Katılımcıların demografik dağılımı

\begin{tabular}{|l|c|c|}
\hline Cinsiyet & Frekans & Yüzde \\
\hline Kadın & 174 & 49,2 \\
\hline Erkek & 180 & 50,8 \\
\hline Toplam & 354 & 100,0 \\
\hline Yaş aralığı & Frekans & Yüzde \\
\hline $18-25$ & 78 & 22,0 \\
\hline $26-35$ & 99 & 28,0 \\
\hline $36-45$ & 75 & 21,2 \\
\hline $46-55$ & 66 & 18,6 \\
\hline $56-65$ & 30 & 8,5 \\
\hline 66 ve üzeri & 6 & 1,7 \\
\hline Ĕgitim düzeyi & Frekans & Yüzde \\
\hline Okur-Yazar değil & 83 & 23,4 \\
\hline Okur-Yazar & 61 & 17,2 \\
\hline İlkokul mezunu & 131 & 37,0 \\
\hline İkokul terk & 9 & 2,5 \\
\hline Ortaokul mezunu & 21 & 5,9 \\
\hline Ortaokul terk & 12 & 3,4 \\
\hline Lise mezunu & 19 & 5,4 \\
\hline Lise terk & 10 & 2,8 \\
\hline Universite mezunu & 5 & 1,4 \\
\hline Universite terk & 2 & 0,6 \\
\hline Yüksek Lisans/Doktora & 1 & 0,3 \\
\hline
\end{tabular}

Görüşülenlerin medeni durum göstergelerini incelediğimizde ise katılımc1ların \%65,3'ünün evli ve aile birlikteliği devam eden 231 kişiden oluştuğu anlaşılmaktadır. Bu birlikteliklerin çoğu Suriye'de başlamış ve Türkiye'de devam eden birliktelikler olsa da, Türkiye'de yapılan yeni evlilik oranı da oldukça yüksektir. Zira Suriye'den ülkemize olan göç hareketlerinin ilk başladığ yıllar olan 2011'den günümüze kadar devam eden sürecini düşündüğümüzde, o zamanlar ortalama 9-10 yaşlarında olan Suriyeli çocuklar, bugün 18-19 yaşlarına gelmiş ve yeni evlilikler yaparak aile birliktelikleri oluşturmuş ve oluşturmaya devam etmektedirler. Diğer katılımcıların medeni durum düzeylerine baktığımızda ise \%13,6'sının hiç evlenmediği, \%8,5'inin eşinin vefat ettiği, \%4,2'sinin eşi/eşini terk etmiş olduğu, \%3,4'ünün evli; fakat eşinin Suriye'de/uzakta olduğu, \%2,5'inin evli fakat eşi cezaevinde/tutuklu olduğu ve \%2,5'inin boşanmış olduğu sonuçlarına ulaşılmıştır.

\section{Mekan ve Yerleşim}

Mekan ve yerleşim yeri özelliği bağlamında, Suriyeli göçmenlerin hane bazlı kişi ve aile sayıları, barınma ihtiyaçlarını karşılama şekilleri ve yerleşim oluşturmadaki tercihlerine göre incelenmiş, aynı hanede yaşayan aile sayısı ile hane bazlı kişi sayısı arasındaki ilişki açısından göçmenlerin genel anlamda tek aile olarak yaşadığı ve 5-7 kişi aralığında nüfusa sahip olduğu bulgulanmıştır. Bununla birlikte önemli bir gösterge, göçmenler arasında birden fazla ailenin aynı hanede yaşıyor ve paylaşıyor oluşudur. Genel anlamda aynı ailenin bekar fertlerinin evlendikten sonra farklı bir evde değil, aynı hanede ailesiyle birlikte yaşamaya devam etmeleri şeklinde oluşan bu geçici geniş aile yaşantısının bir başka oluşum şekli de birincil düzeyde akrabalık ilişkileri bulunan iki veya daha fazla ailenin bir arada yaşaması olarak karşımıza çıkmıştır. Geçici geniş aile yaşantısı, çoğunlukla aile başına düşen kira ve hane masraflarını azaltma düşüncesiyle ekonomik tasarruf temellinde kurgulanmış olsa da, aile fertlerinin bir 
arada yaşama isteklerinin ve kültürel bir alışkanlığın getirisi olduğu görülmüştür. Bununla birlikte yaptığımız mülakatlara, geçici geniş aile yaşantısının aile fertleri üzerindeki psikolojik etkilerinin yanı sıra mahremiyet ihlali, temizlik ve hijyen gibi istenmeyen sorunları da beraberinde taşıdığı eleştirileri yansımıştır.

Suriyeli göçmen ailelerin tamamına yakınının barınma ihtiyacını, kiralama yoluyla edinilmiş evlerde sağladığı görülmektedir. Bunların dışında sadece 3 aile mülk edinmiş, 2 aile ise kira bedeli vermeden ücretsiz olarak ikamet etmektedir. Suriyeli göçmen ailelerin, kiraladıkları konutlar için ödemelerini aylık veya yıllık olmak üzere 2 şekilde gerçekleştirebildikleri, genel olarak ise kiralarını yıllık ve peşin olarak ödedikleri bulgulanmıştır. Ev sahiplerince kiraların ylllık ve peşin olarak alınma nedeni ise göçmenlerin düzensiz gelir sahibi oluşu ve ticari anlamda 1 y1llık kira gelirini garantiye alma düşüncesinden kaynaklanmaktadır. Ödenen kiraların aylık karşılıklarını değerlendirdiğimizde, kiraların 400-499 TL ve 500-599 TL aralığında kümülatif olduğu ve bu fiyat aralığı altında Adana'da ev kiralamanın çok zor olduğu ve ev sahiplerinin ailelerdeki kişi sayısına göre ev kirası belirledikleri görüşmeciler tarafından ifade edilmiştir.

\section{Sosyal ve Mekansal Kümelenme}

Suriyeli göçmenlerin yerleşim alanları üzerinden mekansal yoğunlaşma olgusunu ele aldığımızda, büyük çoğunluğunun akrabalık bağları temelinde aynı mahalle ve bölgede oturmayı tercih ettiklerini görmekteyiz. Suriyeli göçmenlerin yerleşim yeri oluşturmadaki nedensel faktörlerini incelediğimizde, 354 görüşmeciden 123'ü $(\% 34,7)$ oturduğu mahalleye yerleşme sebebi olarak akrabalarının varlı̆̆ını gösterirken, 84 kişi de $(\% 23,7)$ benzer anlamdaki köylüm, memleketlim/tanıdıklarım var cevabını, 45 kişi $(\% 12,7)$ ise Suriyeli göçmen fazla cevabını vermiştir. Suriyeli göçmen ailelerin akraba, hemşeri ya da tanıdıklarına yakın mahalle ve bölgede ikamet etmeyi istemelerinin temelinde ise göçmenler arası yardımlaşma, dayanışma, güvenlik ve kültürlerini koruma düşüncelerinin olduğu ve bu nedenle göç ettikleri, yerleşim bölgelerinde mekansal ve sosyal kümelenmeler oluşturdukları anlaşılmaktadır.

Suriyeli göçmenlerin barınma konusunda yaşadıkları sorunlar incelendiğinde ise en yoğun cevap \%26,3 ile havasız ve rutubetli evlerde oturduklarını belirttikleri sağllksız barınma koşullarıdır. Dünya genelinde göçmen sorunlarının başında gelen sağlıksız barınma koşulları, Adana'da yaşayan Suriyeli göçmenler tarafından da bir sorun alanı olarak gösterilmektedir. Nitekim yapılan görüşmelerde özellikle Suriyeli göçmen kadınların, hiç güneş 1şığı ve hava almayan, rutubetli evlerde yaşadıklarına ilişkin ifadelerle karşılaşılmıştır. Fakat bununla birlikte önemli bir husus, görüşülenlerden çoğunluğunun, mahallelerinde kendilerini güvende hissettiklerini ve başka bir bölgede yaşamayı düşünmediklerini ifade etmeleridir.

Tablo 2. Görüşülenlerin barınma konusunda yaşadıkları sorunlar

\begin{tabular}{|l|c|c|c|}
\hline Barınma konusunda yaşadıkları en büyük sorun & Frekans & $\begin{array}{c}\text { Geçerli } \\
\text { Yüzde }\end{array}$ & $\begin{array}{c}\text { Kümülatif } \\
\text { Yüzde }\end{array}$ \\
\hline Sorun yok & 78 & 22,0 & 28,0 \\
\hline Birden fazla aile/kalabalık yaşam & 21 & 5,9 & 5,9 \\
\hline Mahalle/bölge kötü & 30 & 8,5 & 36,4 \\
\hline Oturduğumuz ev çok küçük/dar & 18 & 5,1 & 41,5 \\
\hline Ev kiram çok yüksek & 84 & 23,7 & 65,3 \\
\hline Evimde eşyam yok & 9 & 2,5 & 67,8 \\
\hline Barınma ihtiyacını karşılayacak maddi gücüm yok & 3 & 0,8 & 68,6 \\
\hline Oturduğumuz ev kötü, havasız, rutubetli vs. & 93 & 26,3 & 94,9 \\
\hline Ev sahibi/komşu tutumu & 18 & 5,1 & 100 \\
\hline Toplam & 354 & 100 & \\
\hline
\end{tabular}


Görüşülenlerce sağlıksız barınma koşullarından sonra en fazla belirtilen sorun alanı kiraların yüksek oluşudur $(\% 23,7)$. Özellikle Suriyeli göçmenlerin geçici barınma merkezleri dışında yaşama istekleri, Adana'da ev kiralarının yükselmesine, oturulmaz olarak bilinen bazı konutların kiralanmasına ve bazı emlakçıların bunu fırsata dönüştürmesine neden olmuştur. Yaşadığı mahalle ve bölgenin yetersiz olduğunu $30(\% 8,5)$ aile belirtirken, $18(\% 5,1)$ aile ev sahibi ve komşu tutumunu bir sorun olarak belirtmiştir. Barınma koşullarına ilişkin farklı sorunlar belirtilmiş olsa da, katılımcıların 78'i (\%22) barınma ile ilgili herhangi bir problem yaşamadığını ifade etmiş ve yerleşim mekanını kabullenmiş görünmektedirler.

\section{Göçün Ekonomi-Politiği}

Görüşülen göçmen grubun istihdama katılımı, çalışma ilişkileri ve ekonomik faaliyetleri; mesleki yeterlilik, çalışma yaşı, çalışma izni ve aylık gelir miktarı üzerinden irdelenmiş ve hanede aktif gelir getiren kişi sayısı sorumuza 12 aile $(\% 3,4)$ hanesinde çalışabilecek nitelikte kimse olmadığı cevabını vermiş ve genel anlamda geçimlerini alınan yardımlarla sağladıklarını belirtmişlerdir. Hanesinde çalışabilecek nitelikte kişi ve kişiler olmasına rağmen çalışmayan 6 aile $(\% 1,7)$, çalışmama gerekçesini işsizlik ve istihdama katılamama olarak ifade etmiştir. Gerçekleştirilen 354 görüşmeden işsizlik gerekçesiyle ve çalışabilecek nitelikte kimsenin olmayışından kaynaklı aktif çalışanın olmadığı 18 aile dışında kalan 336 ailede en az 1 çalışan olduğu, çoğunluk 2 çalışan olmak üzere 3 ve 4 aktif çalışan ailenin olduğu görülmüştür. Görüşme yapılanlardan 132 'sinin (\%37,3) hanesinde tek çalışan olduğu; 141 ailede $(\% 39,8)$ ise 2 aktif çalışan olduğu bulgulanmıştır. Bunların dışında görüşülenler arasında $\% 15,3$ oranında 3 aktif çalışan ve $\% 2,5$ oranında ise 4 aktif çalışan bulunmaktadır.

Suriyeli göçmenlerin temel ekonomik ihtiyaçlarını karşılamada doğrudan bir sorun yaşamadıkları görülmektedir. İkamet edilen haneler ve yaşam koşulları, çoğunlukla standartların altında gözlemlenmiş olsa da, haneye giren gelir miktarı kişi sayısına oranlandığında alım gücünün Türkiye şartlarında normal olduğu söylenmelidir. Hane içindeki yaşam standartlarının alt seviyelerde görünmesi, gelir yetersizliğinden değil; alışılagelmiş yaşam tarzı, kültürel özellikler, geleceğe ilişkin belirsizlik ve başka şehir ya da ülkeye gitme beklentisinde olanların birikim yapma çabalarından kaynaklanmaktadır.

Görüşülen ailelerde haneye gelir getiren bireyler \%64,4 oranında 18 yaş ve üstü yaş grubundan oluşmuştur. Fakat geriye kalan \% 35,6'lık bir oranda, 18 yaş altında çalışan çocukların varlığı dikkat çekicidir. Hanesinde 18 yaş altında ve çocuk işçi konumunda 1 aktif çalışan 84 aile $(\% 23,7)$ bulunurken, 2 çocuk işçi bulunan 36 aile $(\% 10,2), 3$ çocuk işçi bulunan ise 6 aile $(\% 1,7)$ olduğu tespit edilmiştir. Çocuk işçiliğinin en fazla olduğu sektörlerin başında ise tekstil ve geri dönüşüm amaçlı kağıt, plastik ve hurda toplayıcıllğı gelmektedir. Özellikle çok çocuklu ailelerde, okullaşma oranının düştügü ve ücretsiz aile işçiliği şeklinde tanımlanabilecek çocuk işçiliğinin arttı̆̆ gözlemlenmiştir.

Tablo 3. Hanedeki aktif çalışan kişinin para kazandığı/çalıştığı işi/mesleği

\begin{tabular}{|c|c|c|c|}
\hline $\begin{array}{c}\text { Hanede aktif çalışan kişinin para } \\
\text { kazandığı/çalıştığı işi/mesleği }\end{array}$ & Frekans & Geçerli Yüzde & Kümülatif Yüzde \\
\hline Hanede çalışan yok & 12 & 3,4 & 3,4 \\
\hline İş̧aat İşçisi & 24 & 6,8 & 13,6 \\
\hline Öğretmen & 12 & 3,4 & 6,8 \\
\hline Tarım işçisi & 21 & 5,9 & 19,5 \\
\hline Tekstil iş̧̧isi & 71 & 20,1 & 39,5 \\
\hline Mobilya işçisi & 19 & 5,4 & 44,9 \\
\hline Pazarcı & 9 & 2,5 & 47,5 \\
\hline Fırınc1 & 6 & 1,7 & 49,2 \\
\hline Boyacı & 7 & 2,0 & 51,1 \\
\hline
\end{tabular}




\begin{tabular}{|l|c|c|c|}
\hline Lokanta İşçisi & 14 & 4,0 & 55,1 \\
\hline Tamirci & 11 & 3,1 & 58,2 \\
\hline Telefon/İletişim & 8 & 2,3 & 60,5 \\
\hline Kuaför/Berber & 9 & 2,5 & 63,0 \\
\hline Şoför/Nakliyeci & 6 & 1,7 & 64,7 \\
\hline Kağıt/Plastik/Hurda Toplayıcısı & 64 & 18,1 & 82,8 \\
\hline Hamal/Beden İşçisi & 11 & 3,1 & 85,9 \\
\hline Oto Yıamacı & 8 & 2,3 & 88,1 \\
\hline Ayakkabıcı & 17 & 4,8 & 92,9 \\
\hline Elektrikçi & 7 & 2,0 & 94,9 \\
\hline Diğer & 18 & 5,1 & 100 \\
\hline Toplam & 354 & 100 & \\
\hline
\end{tabular}

Tablo-3'e baktığımızda, Suriyeli göçmenlerin en fazla tekstil sektöründe çalıştığı ve istihdam imkanı bulduğu görülmektedir. Türkiye'deki hazır giyim ve konfeksiyon sektöründe en fazla ihracat yapan iller siralamasında ilk 10'da İstanbul, İzmir, Denizli, Bursa, Gaziantep, Tekirdağ, Adana, Düzce, Kahramanmaraş ve Mardin yer almaktadır (AHKIB; Hazır Giyim ve Konfeksiyon Sektörü Temmuz Ayı İhracat Rakamları Değerlendirmesi 2019, 4). Tekstil sektöründe Türkiye'de ilk on arasına girmiş lokomotif illerinden birisi olan Adana'da, Suriyeli göçmenler $\% 20,1$ oranında bu sektörde yer almış durumdadır. Tekstil sektöründen sonra ise en fazla çalışma alanını kağıt, plastik, hurda toplayıcılığı ve benzer türdeki enformel sektör alanları oluşturmaktadır. Özellikle, doğrudan iş imkanı sağlayacak nitelikte bir iş ya da mesleği olmayan Suriyeli göçmenin, \%18,1 oranında geri dönüşüm toplayıcıllğ yaptığ1 ve bu işi özellikle vergi avantajı ve ehliyetsiz kullanılabilmesi nedeniyle tercih edilen 3 tekerli elektrikli motorlar ile yapmakta oldukları saha çalışmamız esnasında gözlemlenmiştir.

Suriyelilerin Adana'da istihdam bulduğu bir diğer çalışma alanı da inşaat sektörüdür. Adana'da özellikle son yıllarda inşaat sektörünün büyümesi, inşaatlarda çalışacak işçi talebini beraberinde getirmiştir. Genel anlamda inşaat sektörünün büyüklüğü ve enformel istihdama olanak sağlayan yapısı, Suriyeli göçmenlerin özellikle bu sektöre yönelmelerine neden olmuştur. Sokaklara çıkıp gözlem yapıldığında, yapılan onlarca inşaatın birçoğunda göçmenlerin çalıştığını görmek mümkündür. Görüşme yapılan Suriyeli erkek nüfusun \%6,8'inin inşaat sektöründe istihdama katıldığı araştırmamızın sonuçlarına yansımış ve doğrulanmış durumdadır.

Görüşülenlerin istihdam alanı içerisinde tarım sektörü de önemli bir orana sahiptir ve kayıt dış1 çalışmaya ve enformel istihdama kaynaklık etmektedir. Nitekim Türkiye'nin en verimli tarım arazilerine sahip Çukurova bölgesi, potansiyeli nedeniyle birçok Suriyeli göçmen aileye geçim kapısı oluşturmuş ve katılımcıların \% 6,8'inin tarım sektöründe iş bulduğu görülmüsstür. Öte taraftan Tablo-3'de görüldüğü üzere tekstil, geri dönüşüm toplayıcıllğı ve inşaat alanlarından sonra mevsimlik tarım işçiliği, ayakkabıcılık, mobilya işçiliği, seyyar satıcılık, pazarcılık gibi diğer enformel çalışma alanları, Suriyeli göçmenlerin çalışma hayatına katılımını kolaylaştırsa da bu durum, göçmenlerin yasal çalışma izni ve çalışma sigortası olmadan kayıtsız ve güvencesiz çalıştırılmalarına yol açmıştır. Görüşmelerimiz kapsamında, ailesinde aktif çalışanın olduğunu belirten 342 aileden sadece $42(\% 11,9)$ aile yasal çalışma izni ve çalışma sigortasına sahiptir. Yasal çalışma iznine sahip olanların iş ve mesleklerine baktığımızda ise, öğretmen, doktor, ustabaşı gibi nitelikli işgücü kapsamında değerlendirilen göçmenler olduğu ve özellikle Suriyeli öğretmenlerin, devlet okullarında Suriyelilere eğitim verdikleri ve maaşlarını UNICEF (Birleşmiş Milletler Çocuklara Yardım Fonu)'den aldıkları ifade edilmiştir. Bu anlamda geriye kalan 300 aile $(\% 84,7)$ arasında yasal çalışma izni ve çalışma sigortasına sahip görüşülen yoktur.

Suriyeli göçmenlerin aylık işgücü gelirleri değerlendirildiğinde standart olarak piyasa şartlarında asgari ücret düzeyinde bir gelir elde etmektedirler. Ancak hanede çalışan kişi sayısı arttıkça aylık gelir miktarı da artmakta ve özellikle ücretsiz aile işçiliği şeklinde görülen çocuk 
işçilikler neticesinde hane gelirleri yükseltmekte ve kişi başına düşen gelir miktarı da buna bağlı olarak artmaktadır. Bu bağlamda bazı ailelerin eve iş aldıkları ve düğme dikme, sakız-şeker paketleme, tütün işleme (sigara), takı-toka ve süs eşyası yapma gibi parça hesabına göre kazanç sağladıkları işleri çocuklarıyla birlikte yaparak haneye ek gelir ürettikleri saha araştırmamız esnasında gözlemlenmiştir.

Tablo 4. Suriyeli göçmenlerin iş konusunda yaşadıkları sorunlar

\begin{tabular}{|c|c|c|c|}
\hline $\begin{array}{c}\text { Suriyeli göçmenlerin, iş konusunda yaşadığı } \\
\text { en büyük sorun nedir? }\end{array}$ & Frekans & Geçerli Yüzde & Kümülatif Yüzde \\
\hline Kötü/ağırışartlarda çalışma & 54 & 15,3 & 15,3 \\
\hline Düşük ücret/maaş & 72 & 20,3 & 35,6 \\
\hline Yasal çalışma izni yok & 36 & 10,2 & 45,8 \\
\hline İş yerinden maaşını alamama & 48 & 13,6 & 59,3 \\
\hline Sağlık güvencesiz çalışma & 33 & 9,3 & 68,6 \\
\hline İşsizlik/İş bulamama & 45 & 12,7 & 81,4 \\
\hline Dil-İletişim sorunu & 9 & 2,5 & 83,9 \\
\hline Haksızlık/Adaletsizlik & 6 & 1,7 & 85,6 \\
\hline Ayrımcılık/Ötekilik & 3 & 0,8 & 86,4 \\
\hline Her hangi bir sorun yok & 33 & 9,3 & 95,8 \\
\hline Fikrim yok & 15 & 4,2 & 100 \\
\hline Toplam & 354 & 100 & \\
\hline
\end{tabular}

Suriyeli göçmenlerin iş konusunda yaşadığı sorunlara, katılımcıların büyük bir oranı $(\% 20,3)$ düşük ücret ve maaş cevabını vermiştir. Bunun dışında ağır şartlarda çalışma $(\% 15,3)$ ve iş yerinden maaş alamama $(\% 13,6)$ sorunu belirtilmiş ve kayıtdışı istihdamın çalışma ilişkilerini olumsuzladığı hususiyetler olarak tanımlanmıştır. Nitekim kayıtdışı istihdam şartlarında Suriyeli göçmenler emek sömürüsüyle karşılaşabilmekte, yasal çalışma iznine sahip olmama ve sağl1ks1z, güvencesiz çalışma ortamları istihdama katılımı olumsuz yönde etkilemektedir. Zira görüşülenlerin \%12,7'si işsizlik ve istihdama katılamamayı bir sorun görmekte, bunların dışında iletişim sorunu, haksızlık/adaletsizlik, ayrımcılık ve ötekileştirme elde edilen diğer cevapları oluşturmaktadır. İş ve istihdam konularında herhangi bir sorun yaşamadığını belirten oranı ise sadece $\% 9,3$ 'tür.

Görüşülen 354 Suriyeli göçmen ailenin kamu, özel sektör ve sivil toplum kuruluşu veya gerçek kişi kaynaklı ayni/nakdi yardım alma durumları incelendiğinde; 147 ailenin $(\% 41,5)$ hiçbir kaynaktan yardım almadığı, geriye kalan 207 ailenin $(\% 58,5)$ ise farklı kaynaklardan ayni ya da nakdi yardım aldığı tespit edilmiştir. Yardım alan ailelerin dağılımına baktığımızda ise 138 aile, Türk Kızılayı'ndan yardım aldığını belirterek Sosyal Uyum Yardımına (Yabancılara Yönelik Sosyal Uyum Yardım Programı olan SUY, Avrupa Birliği tarafindan fonlanmakta olup, Birleşmiş Milletler Dünya Gıda Programı (WFP), Türk Kızılayı (Kızılay) ve Aile, Çalışma ve Sosyal Hizmetler Bakanlığı tarafından ortaklaşa yürütülmektedir. SUY; Türkiye'de Uluslararası Koruma veya Geçici Koruma altında yaşayan, 99'lu kimlik kartına sahip ve yardıma ihtiyacı olanlara nakit yardımı vermektedir. http://kizilaykart-suy.org/TR/faq0.html) Son erişim 01.01.2020) işaret etmiştir. Bu verinin dışında, diğer yardım kanalları irdelendiğinde doğrudan kamu/devlet kaynaklı yardım alan ailelerin sayısının azlığı göze çarpmaktadır. Kamuoyunda 'Devlet tüm Suriyelilere maaş veriyor', algısının yanlış olduğu; söz konusu yardımların Avrupa kaynaklı fondan sağlanan SUY Programı olduğu görülmektedir.

Suriyeli göçmen ailelerin, Türk Kızılayı dışındaki sivil toplum kuruluşu kaynaklı yardım durumlarına baktığımızda, farklı ulusal ve uluslararası dernek ya da vakıfların ayni ve nakdi yardımda bulundukları anlaşılmıştır. Ulusal dernek ve vakıflardan $\dot{I} H H$, Hayata Destek, Dosteller isimleri ön plana çıkarken; WFP, ASAM, UNICEF ise uluslararası dernek ve vakıflar 
olarak belirtilmiştir. Hiçbir kaynaktan yardım almayan 147 aile dışındaki Suriyeli diğer göçmen ailenin aylık yardım miktarının ise hane bazlı ve kişi sayısına bağlı olarak değiştiği görülmektedir. Bu bağlamda haneye giren ayni ve nakdi yardımların aylık karşılığı 1-199 TL olan 33 aile (\%9,3), 200-499 TL olan 45 aile (\%12,7), 500-799 TL olan 51 aile $(\% 14,4), 800-1099$ TL olan 39 aile $(\% 11,0), 1100-1399$ TL olan 30 aile $(\% 8,5)$ ve $1400-1699$ TL olan 9 ailenin $(\% 2,5)$ olduğu ve hanedeki kişi sayısı arttıkça, yapılan yardım miktarının da aynı oranda arttığı sonuçlarına ulaşılmıştır.

\section{Kadın ve Evlilik}

Kadın göçmen nüfusunun, göç sürecinin zorluklarından en fazla etkilendiği tartışılmazdır. Özelikle eşi vefat etmiş, çocuklu ya da yaşlı kadın göçmenlerin yaşadığı sorunlar dışında, istismara uğrama, erken yaş evlilik, kamusal hizmetlere sınırlı erişim ve yalnızlaşma gibi durumlar sıklıkla karşılaşılan görünümlerdir. Bu çerçevede araştırmamız dahilinde görüşülenlere yöneltilen kız çocukları için uygun evlilik yaşı kaçtır sorusuna katılımcıların yarısından fazlası (\%55'i) 18 yaş cevabını vermiştir. Ancak görüşülenlerin \%27,9'u 18 yaş altı evlilikleri olağan karşılamış ve 16 ve 17 yaşında evlilik yapılmasında bir sakınca olmadığını belirtmişlerdir. Her ne kadar görüşülenlerin geriye kalan \%16,9'u 18 yaş üstü evlilikleri uygun yaş dönemi olarak belirtilmiş olsa bile kız çocuklarının evlilik yaşı hakkında gerçekçi olmayan beyanların yapıldığı gözlemlenmiştir. Zira bazı göçmenlerin Türkiye'de 18 yaş altı evliliğin yasal olmadığını bilmesinden dolayı şaşırtma cevap verdiği ve 18 yaş altı evliliklerin varlığını gizli tutmaya çalıştıkları görülmüştür.

Tablo 5. Görüşülenlerin evlilik yaşı, başlık parası ve çok eşliliğe bakışı

\begin{tabular}{|c|c|c|c|}
\hline $\begin{array}{c}\text { Suriyeli bir göçmen olarak, sizce bir } \\
\text { kadın için uygun evlilik yaşı kaç } \\
\text { olmalıdır? }\end{array}$ & Frekans & Geçerli Yüzde & Kümülatif Yüzde \\
\hline 16 & 15 & 4,2 & 4,2 \\
\hline 17 & 84 & 23,7 & 28,0 \\
\hline 18 & 195 & 55,1 & 83,1 \\
\hline 19 & 36 & 10,2 & 93,2 \\
\hline 20 & 18 & 5,1 & 98,3 \\
\hline 21 & 3 & 0,8 & 99,2 \\
\hline Toplam & 3 & 0,8 & 100 \\
\hline Bu hanede 18 yaş altında evlenen kadın & 354 & 100 & \\
\hline var mı? & & & Kümülatif Yüzde \\
\hline Hayır, yok & 162 & 45,8 & 45,8 \\
\hline Evet, var & 192 & 54,2 & 100 \\
\hline Toplam & 354 & 100 & \\
\hline
\end{tabular}

Görüşülenlerin \%65,3'ü hanesinde başlık parası ödeyen kimse olmadığı belirtse de, araştırmamıza yansıyan oranların dışında başlık parası geleneğinin yaygın biçimde varlığını devam ettirdiği görülmüştür. Zira başlık parası, Suriyeli göçmenlerce geleneksel olarak korunmakta, kültürel olarak üretilmekte ve sosyo-ekonomik statüye bağlı olarak şekillenmektedir. Bu manada $123(\% 34,7)$ görüşmeci, yerel halk ya da Suriyelilerle yapılan evliliklerde başlık parası alındığını ifade etmiş ve hanesinde ikinci bir eşi (kadın) olan (\%9,3) 33 kişi ve aile tespit edilmiştir. Mülakatlarımızda ikinci eş olmayı kabul eden kadınların görece ekonomik gelir düzeyi düşük ailelerden geldiği ve ikinci eş olarak evlenmeyi de yaşadığı hayattan kurtulmanın bir yolu olarak değerlendirdikleri bulgulanmıştır. Bununla birlikte ikinci eş olarak evlenmenin dini ve kültürel dayanaklarının meşrulaştırıldığı, çok kadın ile evlenmenin İslami inanca göre Peygamber sünneti olduğu, Suriye'de çok eşli evliliğin normal karşılandığı ve çocuğu olmayan kadınların 
kocasına 2. eş ile evlenme izni verdiğine ilişkin ifadeler yer almıştır. Ancak Suriyeli göçmenlerin Türkiye'deki bulunma süreleriyle orantılı olarak, çok eşli evlilik tercihinin azaldığı ve yerel kültürel pratiklerin benimsenmeye başlandığı da özellikle vurgulanmalıdır.

\section{Kimlik ve Aidiyet}

Örneklem grubunu oluşturan Suriyeli göçmenlere, “Kendinizi öncelikli olarak hangi kimlikle ifade ediyorsunuz?" sorusuna \% 93,2 oranında Müslüman cevabı verilmiştir. Bu manada dini kimlik, etnik ve ulusal kimliğin önünde yer almış ve kamusal alanda dini kimliği kullanmak daha faydalı görülmüştür. Öte taraftan ilk kimlik tanımında kendisini Arap olarak tanımlayan 6 kişi $(\% 1,7)$, Türkmen olarak tanımlayan 3 kişi $(\% 0,8)$ ve Kürt olarak tanımlayan 9 kişi $(\% 2,5)$ bulunmaktadır. Ayrıca diğer seçeneği içerisinde ilk kimlik tanımlamasında Süryani, Çerkez ve Ermeni cevabını veren 6 kişi $(\% 1,7)$ vardır. Görüşülenlerin ikinci sırada kullandıkları kimlik tanımlamasında ise Arap kimliği \% 71.2 ile birinci sırada yer almaktadır. Bu verilerin dışında yapılan mülakatlarda farklı kültür ve kimliğe sahip olanların bulunduğu (Ermeni, Süryani, Dürzi) ancak doğrudan kimlik beyanında bulunmaktan kaçındıklanı gözlemlerimize yansımıştır.

Tablo 6. Katılımcıların kendilerine ilişkin kimlik tanımları

\begin{tabular}{|c|c|c|c|}
\hline $\begin{array}{c}\text { Kendinizi ilk olarak hangi kimlikle ifade } \\
\text { ediyorsunuz? }\end{array}$ & Frekans & Geçerli Yüzde & $\begin{array}{c}\text { Kümülatif } \\
\text { Yüzde }\end{array}$ \\
\hline Müslüman & 330 & 93,2 & 93,2 \\
\hline Arap & 6 & 1,7 & 94,9 \\
\hline Türkmen & 3 & 0,8 & 95,8 \\
\hline Kürt & 9 & 2,5 & 98,3 \\
\hline Diğer & 6 & 1,7 & 100 \\
\hline Toplam & 354 & 100 & \\
\hline
\end{tabular}

Görüşülenlerin anadili ve anadili kullanma oranlarına baktığımızda ise Suriyeli göçmen nüfusun \%78.8'i Arapçay1 \%9.3'ü Kürtçeyi ve \%11.9'u da Türkçeyi anadili olarak belirtmiştir. Göç alınan Suriye'deki bölgeler bağlamında değerlendirildiğinde Halep ve çevresinden gelenlerin $(\% 78,8)$ Arapçayı; Afrin, Ayn-el Arap, Amude ve yakınındaki yerleşimlerden göç edenlerin ağırlıklı olarak Kürtçeyi; Hama, Humus, Rakka ve civar yerleşimlerden gelenlerin ise Türkçe konuştukları bulgulanmıştır.

Tablo 7. Katılımcıların dil, din ve mezhep dağılımları

\begin{tabular}{|c|c|c|c|}
\hline Anadiliniz? & Frekans & Geçerli Yüzde & Kümülatif Yüzde \\
\hline Arapça & 279 & 78,8 & 78,8 \\
\hline Kürtçe & 33 & 9,3 & 88,1 \\
\hline Türkçe & 42 & 11,9 & 100 \\
\hline Hangi dine mensupsunuz? & Frekans & Geçerli Yüzde & Kümülatif Yüzde \\
\hline İslamiyet & 351 & 99,2 & 99,2 \\
\hline Hristiyanlı & 3 & 0,8 & 100 \\
\hline $\begin{array}{c}\text { Kendinizi hangi mezhebe/inanca ait } \\
\text { hissediyorsunuz? }\end{array}$ & Frekans & Geçerli Yüzde & Kümülatif Yüzde \\
\hline Alevi/Nusayri & 27 & 7,6 & 7,6 \\
\hline Sünni & 306 & 86,4 & 94,1 \\
\hline Şii & 9 & 2,5 & 96,6 \\
\hline Dürzi & 9 & 2,5 & 99,2 \\
\hline Diğer & 3 & 0,8 & 100 \\
\hline Toplam & 354 & 100 & \\
\hline
\end{tabular}


Görüşmeye dahil olan Suriyeli göçmen ailelerin \%99,2'si İslam, \%0,8'i de Hristiyanlık dinine mensuptur. Tablo-7 incelendiğinde, 354 ailenin 306's1 kendisini $(\% 86,4)$ Sünni, 27 aile $(\% 7,6)$ ise Nusayri/Alevi olarak tanımlamıştır. Bu manada Suriyeli göçmenler çoğunlukla Arap kökenli, Müslüman ve Sünni inanca sahip görünmektedir. Fakat anket uygulaması esnasında bazı görüşülenler, sorular karşısında duraksayarak cevap vermiş, hakim ve baskın yerel kimlikle uyumlu tanımlama yapmayı tercih etmiştir. Nitekim gözlem ve mülakatlarımızda özellikle Nusayri inancına sahip olanların kimliklerini gizledikleri, gerçekte Beşşar ya da Esed adını verdikleri çocuklarını, Türkiye'de Ahmed ya da Mahmud gibi yaygın isimlerle tanıttıkları gözlemlenmiştir. $\mathrm{Bu}$ bağlamda Suriyeli göçmenlerin kimlik tanımlamalarında güçlü olana benzeme ya da kimliğini gizleme gibi strateji içerisinde oldukları dikkate alınmalıdır. Bunun dışında Suriyeli göçmen nüfusun heterojen ve farklı dil, din ve mezhep farkl11ıklarına sahip olduğu göz önünde bulundurulmalı ve hangi Suriyeli üzerinden tanımlama yapılıp konuşulduğu önemli bir husus olarak değerlendirilmelidir.

\section{7. İçe Kapanma ve Sınırı İletişim}

Kent nüfusunun mekansal dağılımında göçmen kümelenmeleri, bütünleştirici ve bir araya getirici bir işlev yüklense de, yaşanılan ülkedeki uyum sürecini zayıflatan ve olumsuz etkileyebilen bir süreçtir. Bu çerçevede Suriyeli örnek grubumuza "Mahallenizde görüsstügünüz yerli komşular, aileler var mı"' sorusuna 249 aile $(\% 70,3)$ iletişimde bulunduğu yerli bir ailenin olmadığı cevabını vermiştir. Görüşülenlerce yerli halk ile iletişimsizliğin en büyük sebebi dil sorunu olarak belirtilmiş, Suriyeli göçmenlerin Arapça bilen yerli halk ile de yüksek düzeyde ilişki kurmadıkları, kendi dünyaları içerisinde izole bir yaşamı tercih ettikleri ve zorunlu olmadıkça kimseye kapılarını açmadıkları belirlenmiştir. Bu manada görüşülenlerin göçmen yaşam biçimi ve yaşanan zorlukları öncelikli olarak bireysel çözülmeye çalıştığ 1 ve sosyal ve ekonomik ihtiyaçlara göre kamusal alanda bulunmayı tercih ettikleri görülmektedir.

Suriyeli göçmenlere karşı sergilenen bazı dışlayıcı yaklaşım ve söylemlerin, göçmenleri kendi yapısal bütünlüklerini korumaya yönelten bir kapalılığa itmesinin dışında sosyal ve mekansal kümelenmeye de yol açtığı vurgulanmalıdır. Zira Suriyeli göçmen nüfusa yönelik toplumsal algının yüksek düzeyde olumsuz oluşu, kültürel asimilasyon endişesi ve güvenlik gibi gerekçelerle içe kapanma eğilimlerini artırmakta ve sosyal uyum sürecinin uzamasına yol açmaktadır.

Araştırma örneklemimizde yer alan Suriyeli göçmenlerin en fazla oranda ziyaret ettikleri Suriyeliler caddesine görüşülenlerin 159'u (\%44,9) haftada 2-3 kez, \%10,2'si haftada $1 \mathrm{kez}$, $\% 5,1$ 'i ise her gün gitmektedir. Suriyeliler Caddesi bir yerleşim bölgesi olmasının dişında hem ticari bir alan hem de bir sosyalleşme mekanıdır. Suriyeli esnaftan alışveriş yapıyor olmak büyük oranda desteklemekte, görüşülenlerin $\% 32,2$ 'si dil ve iletişim sorunu yaşamadıklarını, $\% 21,2$ 'si rahat alışveriş yaptıklarını, \%32,2'si uygun hizmet aldıklarını ve diğer katılımcılarda daha ucuz, daha güvenilir ve veresiye alışveriş yapabildiklerini belirtmişlerdir. Öte taraftan yerel esnaftan zorunlu olmadıkça alışveriş yapmayan aileler olduğu gibi $(\% 63,6)$, fiyat karşılaştırması yaparak uygun fiyatlı ürünü yerel esnaftan almayı tercih edenlerin oranı \%36,4'tür ve bu oran yerel halk ile kurulan sınırlı iletişimi ekonomik bağlamda göstermesi açısından önemlidir.

\section{Göç ve Sosyal Uyum}

Türkiye'de Aralık 2019 itibariyle geçici koruma kapsamı altında bulunan Suriyeli göçmen sayıs1 3.571.030 olup bu sayının \%53.95'ini erkekler, \%46.05'ini kadınlar oluşturmaktadır. Gelen göçmen nüfusun büyük bir oranının orta yaş ve altındaki yaş gruplarını yansıttı̆̆ı, erkek nüfusunun kadın nüfusundan daha fazla olduğu söylenmelidir. Öte taraftan araştırmamız 
çerçevesinde örneklem grubunu oluşturan göçmenlerin \%67,8'sinin şehir ve kırsal yerleşim yerleri dahil olmak üzere Suriye'nin Halep kentinden geldiği görülmektedir. Bunu takip eden en yakın istatistik, 24 kişinin \%6, $8^{\prime}$ lik oranı olup, sırasıyla İdlib, Deyrizor, Şam, Haseke ve diğer yerleşimlerden gelenler oluşturmaktadır. Ancak bu verilerin dışında bazı görüşülenlerin göç ettiği yere ilişkin bilgi vermekten güvenlik gerekçeli kaçındığı ifade edilmelidir. Öte taraftan göç edilen yer ile Türkiye'nin coğrafi sınır yakınlığı dikkati çekmekte ve göç sürecinde belirleyici bir rol oynamış bulunmaktadır.

Kalma süreleri bağlamında, Suriyelilerin \%39,8'inin (141 aile) ortalama 7-8 yıldır Türkiye'de bulunduğu ve ilk gelen göçmen gruplarından oluştuğu anlaşılmaktadır. Bununla birlikte, 8 yıldan fazla süredir Türkiye'de bulunan 24 aile Suriye iç savaşının başladığı dönemde gelmiş ve 1 yıldan az süredir Türkiye'de olduğunu beyan eden 12 aile $(\% 3,4)$ Suriyeli göçünün halen devam ettiğini göstermektedir.

Suriyeli göçmenlerin Türkiye'de yaşama ve sosyal hayata uyum süreçlerine baktığımızda ise 153 ailenin $(\% 43,2)$ kararsız cevabını verdiğini görmekteyiz. Göç sürecinin belirsizliği, arada kalma durumu ve göçmen psikolojisini yansıtan bu veri gerçekte sosyal uyum ve aidiyete ilişkin yeterli sosyal içerme politikalarının geliştirilememesi olarak değerlendirilmelidir. Bunun dışında göçmen grupların sosyal sisteme entegre edilememesi durumunda pek çok sosyal soruna davetiye çıkaracağ 1 göz önünde bulundurulmalıdır.

Tablo 8. Türkiye'de yaşamaya ve sosyal hayata ne derece uyum sağlayabildiğinizi düşünüyorsunuz?

\begin{tabular}{|c|c|c|c|}
\hline $\begin{array}{c}\text { Türkiye'de yaşamaya ve sosyal hayata ne derece } \\
\text { uyum sağlayabildiğinizi düşünüyorsunuz? }\end{array}$ & Frekans & Geçerli Yüzde & Kümülatif Yüzde \\
\hline Hiç uyum sağlayamadım & 33 & 9,3 & 9,3 \\
\hline Uyum sağlayamadım & 114 & 32,2 & 41,5 \\
\hline Kararsızım & 153 & 43,2 & 84,7 \\
\hline Uyum sağladım & 51 & 14,4 & 99,2 \\
\hline Tamamıyla uyum sağladım & 3 & 0,8 & 100 \\
\hline Toplam & 354 & 100 & \\
\hline
\end{tabular}

Görüşülenler arasında Türkiye'ye uyum sağladığııı belirten oranı $(\% 14,4)$ ve tamamen uyum sağladığını belirten oranı ise \%0,8'dir. Öte taraftan hiç uyum să̆layamadiğını belirten 33 aile $(\% 9,3)$, uyum sağlayamadığım cevabını veren ise 114 aile $(\% 32,2)$ bulunmaktadır. Elde edilen veriler bağlamında Suriyeli göçmenlerin uyum süreçlerini; tamamlanmış uyum, olgunlaşmamış uyum ve uyumsuzluk olarak tanımlamak mümkündür. Diğer bir ifadeyle Suriyeli göçmen nüfusun büyük bir çoğunluğunun sosyal uyum politikalarına ihtiyaç duyduğu vurgulanmalıdır. Nitekim sosyal uyum süreci, göçmenlerin sosyal ve ekonomik statüsü ve yerleşilen yerin kabul koşullarıyla bağlantılı gelişmekte, göçmenler ile yerel halk arasındaki yeni bir toplumsal sözleşmeyi ve politik kararlığı gerekli kılmaktadır.

\section{Sonuç ve Değerlendirme}

Düzensiz göç gruplarının ortaya çıkardığı en önemli sorun alanı, göç nüfusunun niteliği ve yeni gelen nüfusunun sosyal sisteme katılımının sağlanması ihtiyacıdır. Zira sosyal ve mekansal bütünleşme problemlerinin önemli bir kısmı sosyal yapı kaynaklıdır ve göç edilen bölgenin sahip olduğu imkanlarla bağlantılı gelişmektedir. Bu manada göç edilen yerin sosyal ve fiziksel ortamının yeni göçmenler için yönlendirici olup olmama durumu sosyal uyumu belirleyen bir özelliktir. Sağlıklı bir planlama yapılamadığında, göç grupları kent sosyal dokusu içerisinde sosyal adacıklar ya da içe kapanmış mahalleler oluşturması kentin sosyal ve fiziki bölümleri içerisinde sosyal ve mekansal ayrışma sorununa yol açmakta ve sürdürülebilir bir çözüme ihtiyaç duyurmaktadır. 
Göç gruplarının taşımış olduğu kültürel özellikler; nüfusun niteliği, ekonomisi, yaş grubu, cinsiyeti, eğitim durumu ve dünya görüşü göç sürecinin esaslı belirleyicileri olarak çalışmakta ve sosyal işleyiş ve toplumsal dinamikleri farklı boyutlarla etkilemektedir. Zira göç ile kimlik arasında doğrusal bir ilişki vardır ve göç süreci tek başına bir insan hareketliliği olmayıp sosyal ve kültürel aktarımın da dahil olduğu dinamik bir yapıyı ifade etmektedir. Bu aktarım sürecinde insan kendi benliğiyle birlikte dil, din, mezhep, yaşam tarzı, kültür, kimlik gibi bu benliği oluşturan birçok öğeyi de yanında getirmektedir. Bu çerçevede uluslararası göçmenlerin, göç ettikleri ülkelerdeki yaşantıya uyum sağlayabilmek, hayatlarını sürdürebilmek ve daha önemlisi kültürlerini ve kimliklerini muhafaza edebilmek amacıyla bazı yaşam pratiklerini geliştirdikleri ve kendi aralarında dayanışma ve güven duyguları temelinde aile, akrabalık, hemşerilik, etnik ya da dini bağlar gibi sosyal ve ilişkisel ağlar kurdukları görülmektedir.

Araştırmamızın sonuçları bağlamında değerlendirildiğinde, Türkiye'deki Suriyeli nüfusun büyük bir çoğunluğunun $(\% 71,2)$ orta yaş ve altı gruptan ve genel anlamda çalışabilir, üretebilir ve dinamik bir yaş grubundan oluştuğu görülmektedir. Bu oran Türkiye'ye göç etmiş Suriyeli nüfusu ile de doğru orantılıdır ve Suriyeli göçmenlere ilişkin kamusal tartışmalarda dikkate alınması gereken bir özelliktir. Göçmen nüfusunun demografik dağılımlarına göre üzerinde durulması gereken diğer bir konu eğitim düzeylerinin düşük oluşudur. Neredeyse her 4-5 göçmenden birisinin okuma yazma bilmediğine ilişkin veriler sosyal uyum ve sosyal sisteme katılımda önemli bir sorun alanı ve çözülmesi gereken bir bulgudur. Zira göçmenlerin eğitim düzeyi kadar mesleki yeterlilikleri ve istihdama katılım imkanları eğitim durumuyla yakından ilişkili bulunmakta ve kayıtsız istihdam süreçlerini beslemektedir.

Suriyeli göçmenlerin büyük bir oranının $(\% 65,3)$ evli ve aileleriyle birlikte göç etmiş olmalarına karşın, çok eşli evlilik ve 18 yaş altı evliliklere imkan tanıyan kültürel alışkanlıkları araştırma sonuçlarımıza yansıyan başka önemli bir bulgudur. Bir anlamda kültürel özellikler ve İslami inançtan beslenen çok eşle evlilik Türkiye'deki 18 yaş altı evliliğin yasal olmaması ile çelişmekte ve meşrulaştırıcı bazı söylemlerle durumun devamlılığının sağlandığı görülmektedir. Bunun dışında başlık geleneği üzerinden 18 yaş altındaki birçok Suriyeli kız çocuğunun evlendirilmesine, 2. eş olmasına, yerli ya da Suriyeliler ile evlendirilmesine olumla bakılmaktadır. Özellikle ekonomik durumu iyi olmayan ailelerin başlık parasını bir gelir kapısı olarak görmesi de bu evlilik biçimlerini yaygınlaştırmaktadır. Bu manada göçmen çocuklarının eğitim sistemi içerisinde yer almasının, eşi vefat etmiş ve tutuklu kadınlara yönelik olarak da destekleyici projeler geliştirmenin faydalı olacağı düşünülmelidir.

Göçmen nüfusun barınma sorununun uzun bir süre sağlıksız ve aynı evi paylaşma biçiminde sürdürülemeyeceği göz önüne alındığında konut ihtiyacının varlığı dikkate alınması gereken bir konudur. Her ne kadar başlangıçta Suriyeli nüfusun ülkelerine geri döneceğine ilişkin bir kamusal alg1 oluşmuş ise de geçen 9 yıllık süreçte birçok Suriyeli bebeğin Türkiye'de doğduğu ve vatandaşlık hakkı alanlarla birlikte sorunun düşünülenden daha kapsamlı olduğu görülmektedir. Benzer biçimde Suriyeli nüfusun kentin mekansal dağılımı içerisinde ürettiği yoğunlaşma ve kümelenmelerin gelecekte kent sosyal sistemi için bir tehdit oluşturması ve kent estetiği yanında bazı sosyal problemlere yol açması muhtemeldir. Bu manada geçici geniş aile yaşantılarının, aynı evi paylaşan kişi sayısının ve oturulan evin ve fiziki ortamın uygunluğunun yeniden değerlendirilmesine ve çözümlenmesine ihtiyaç vardır. Zira göçmen nüfusun yoğunluğu karşısında Adana'da ev kiraları yükselmiş ve pek çok konut oturulamaz koşullarda olmasına karşın Suriyeli göçmenler tarafından kullanılır hale gelmiştir. Ancak bu durum aile içi ilişkilerde mahremiyet ihlali, hijyen ve psikolojik bazı sorunları ortaya çıkarmış ve sosyal uyumu öteleyen bir hal almıştır.

Suriyeli göçmenlerin aynı mahalle ve bölgede yerleşmiş olmasının temelinde en büyük etken göçmenler arası yardımlaşma, dayanışma, güvenlik ve kültürlerini koruma düşünceleridir. 
Fakat dikkati çeken bir sonuç, görüşülenlerin önemli bir kısmının oturduğu mahalleden şikayetçi olmasına karşın kendilerini güvende hissetmeleri ve başka bir bölgede yaşamayı düşünmeyişleridir. $\mathrm{Bu}$ noktada görüşülenlerin sosyo-ekonomik olarak kendilerini yetersiz hissetmesi ve göç sürecinin taşımış olduğu zorluklar nedeniyle yeni bir mekan tasavvuru geliştirememeleri olarak görülmektedir. Diğer bir etken kültürel farklılıklar ve iletişim kurumama gibi kamusal alana katılımı etkileyen özelliklerdir. Bunların dışında oturduğu mahalleyi içselleştirmiş olanların daha çok Suriye'nin kırsal bölgelerinden gelenlerden oluştuğu ve yaşadığ

Görüşülenlerin sosyal sisteme katılımda karşılaştıkları başka önemli bir sorun göçmen nüfusun mesleki yeterliliği ve çalışma ilişkileridir. Nitekim yaklaşık 300 aile/göçmenin yasal çalışma izni ve çalışma sigortası bulunmamaktadır. Hanesinde aktif gelir getiren olmadı̆̆ını belirten aileler çoğunlukla bazı dernek ve vakıflardan ayni ve nakdi yardımlarla geçimlerini sağlamaya çalışırken, işsizlik ve istihdama katılamamayı bir sorun olarak görenlerin varlığ üzerinde durulması gereken bir noktadır. Diğer taraftan göçmen nüfusun büyük bir çoğunluğu kayıtsız istihdam koşulları içerisinde yer almakta ve ailesinde birden fazla gelire sahip olan bireyler bulunmaktadır. Çok çocuklu ailelerde karşılaşılan çocuk iş̧̧iliği ve eve iş alma durumu gelir seviyesini yükseltmiş olsa bile, çocukların eğitimini engelleyen bir sonuçtur. Bunların dışında göçmen nüfusun kayıt dışı istihdam alanlarında; tarım, tekstil, inşaat ve geri dönüşüm toplayıcılığı gibi mevsimlik ve geçici işleri yapıyor oluşunun emek sömürüsüne yol açtığına dikkat edilmelidir. Diğer önemli bir bulgu görüşülenlerin bir kısmının Suriye'ye geri dönme beklentisi ya da başka bir ülkeye gitme düşüncesi içerisinde oluşu ve birikim yapma çabası sergilemesidir. Nitekim göçmen statüsü nedeniyle yaşanılan belirsizlikler ve aidiyet ilişkisi kuramama göçmenlerin kendilerini koruma düşüncelerini besleyen bir özelliktir.

Türkiye kamuoyunda bazı gruplarca gündeme getirilen ve Suriyelilere devletin yardım yaptığı ve aylık maaş bağladığına ilişkin tartışmaların ise gerçekte var olmadığı araştırmamızın önemli bir bulgusudur. Görüşülen 354 Suriyeli göçmen ailenin 147'si hiçbir kaynaktan yardım almadığı, geriye kalan 207 ailenin $(\% 58,5)$ ise farklı kaynaklardan ayni ya da nakdi yardım aldığı tespit edilmiştir. Alınan yardımlarda ise Sosyal Uyum Yardımı ön plana çıkmış, yerel dernek vakıflardan Türk Kızılayı, İHH, Hayata Destek, Dosteller ile uluslararası WFP, ASAM, UNICEF gibi kurum ve kuruluşların yardımda bulunduğu görülmüştür. Bunun dışında bazı yerli vatandaşların ve esnafin Suriyeli göçmenleri muhacir olarak değerlendirdiği ve aile bazlı yardımlarda bulunduğu bilinmektedir. Ancak alınan yardımların ne kadar sürdürülebilir olduğu ve göçmen nüfusun ihtiyaçlarını karşılayarak sosyal sisteme katılımlarını sağlayacağı tartışılabilir bir konudur.

Görüşülenlerin en büyük sorun alanlarından birisi dil ve iletişim sorunu olarak karşımıza çıkmış ve yeterli düzeyde Türkçe dil becerisine sahip olmamak Suriyeli göçmenlerin sınırlı sosyalleşme kanalları içerisinde bulunmasına yol açmıştır. Bu manada göçmenleri Türkçe dil ve iletişim imkanlarını geliştirici kurs ve eğitimlerin düzenlenmesinin yararlı olacağı düşünülmektedir. Özellikle Türkiye'ye uyum sağlayamadığını belirten $(\% 32,2)$ lik oranın yüksekliği ve sosyal uyumun yerleşilen yerin kabul koşullarıyla bağlantılı olduğu dikkate alınmalıdır. Benzer biçimde göçmenlerin kimlik tanımlamalarında karşılaşılan kendini gizleme durumunun ortadan kaldırılmasına yönelik daha kapsayıcı, birey temelli ve karşılıklı biraradalıklar üreten projeler geliştirmenin sosyal uyumu kolaylaştırıcı olacağı öngörülmektedir. Dahası Suriyeli göçmenlere yönelik üretilen olumsuz yaklaşım, dışlayıcı söylem ve önyargıları azaltıcı iyi örnekler, kamusal anlamda çoğaltılarak paylaşılmalı ve sunulmalıdır.

Son söz olarak Suriyeli göçmen nüfus, Türkiye'ye bir ekonomik talep artışı ve ekonomik canlılık kazandırmış olsa da, düzensiz ve büyük oranlı göç nüfusu, yüksek maliyet ve alt yapı ihtiyacını ortaya çıkarmıştır. Özellikle uluslararası mali desteğinde beklenilen oranda olmadığı 
göz önüne alındığında göçmenlerin yaşam koşullarını iyileştirmede ve geleceğe hazırlamada sağlanan ayni ve nakdi yardımların yetersiz kaldığı görülmüştür. Bunun dışında göçmen nüfusun vasıfsız işgücü gerektiren sektörlerde ucuz işgücü açığının gidermedeki olumlu rolü, istihdam alanlarında haksız rekabet ve gerginliklere zemin hazırlamış ve kayıt dışı çalışma koşulları vergi kayıplarına yol açmış bulunmaktadır. Bu nedenle Suriyeli göçmenlerin içinde bulunduğu belirsizliklerin ortadan kaldırılmasına, hukuki statüleri ve konumlarına ilişkin daha rasyonel tanımların yapılmasına, alt yapı imkanlarının güçlendirilmesine ve politik kararlılığa ihtiyaç duyulduğu düşünülmektedir.

\section{KAYNAKÇA}

AFAD (2013). Türkiye'deki Suriyeli Gö̧̧menler Saha Araştırması Sonuçları. T.C. Başbakanlık Afet ve Acil Durum Yönetimi Başkanlığı Yayınları, Ankara 2013. Kaynak: http://www.madde14.org/images /a/a8/AFADSurSigin2013.pdf

Aygül H. H. (2018). "Mültecilerin İşgücüne Katılımı ve Piyasaya Dair Deneyimleri”. Ds. Aygül, H. H. \& Eke, E. 21.Yüzyılda Uluslararası Gö̧ ve Mülteciler: Bir Türkiye Perspektifi. Ankara (2018) 179-210.

Bartel A. P. (1989). "Where Do the New U.S. Immigrants Live?". Journal of Labor Economics 7/4 (1989) 371-391.

Borjas G. J. (1992). "Ethnic Capital and Intergenerational Mobility". Quarterly Journal of Economics 107/1 (1992) 123-150.

Chiswick B. R. \& Miller P. W. (2004). "Where Immigrants Settle in the United States". Journal of Comparative Policy Analysis 6/2 (2004) 185-197 https://doi.org: 10.1080/1387698042000273479

Çetin T. (2010). Bulgaristan'dan Gö̧̧ Eden Türk Nüfusun Dağıllşılnı Etkileyen Coğrafi ve Kültürel Faktörler. Ankara Üniversitesi Türkiye Coğrafyası Araştırma ve Uygulama Merkezi (TÜCAUM) VI. Ulusal Coğrafya Sempozyumu. Ankara 2010.

Deniz A. \& Özgür E. M. (2010). "Rusya'dan Türkiye’ye Uluslararası Göç: Antalya’daki Rus Göçmenler”. Ege Coğrafya Dergisi 19 /1 (2010) 13-30.

Deniz O. (2009). "Mülteci Hareketleri Açısından Van Kentinin Durumu ve Kentteki Mültecilerin Demografik Profili". Doğu Coğrafya Dergisi 14/22 (2009) 187-204.

Güleç S. (2017). "Mekan-Kimlik Etkileşimi: Kavramsal ve Kuramsal Bir Bakış". MANAS Sosyal Araşttrmalar Dergisi 6/1 (2017) 13-37.

Harunoğulları M. \& Cengiz D. (2014). "Suriyeli Göçmenlerin Mekansal Analizi: Hatay (Antakya) Örneği”. TÜCAUM VIII. Coğrafya Sempozyumu Bildiriler Kitabı, 23-24 Ekim 2014. Ankara 2014.

Harvey D. (2013). Sosyal Adalet ve Şehir. Çev. Mehmet Moralı. İstanbul 2013.

Hugo G. (2011). "Changing Spatial Patterns of Immigrant Settlement". Multiculturalism and Integration: A Harmonious Relationship (Michael CLYNE ve James JUPP Eds.) Australia 2011.

International Rescue Committiee (2012). Urban Refugees, November 2012, Kaynak: https://www.rescueuk.org/sites/default/files/document/986/201112urbanrefsforechoadvocacyevent0.pdf

Kolukırık S. (2006). "Bulgaristan'dan Göç Eden Türk Göçmenlerin Dayanışma ve Örgütlenme Biçimleri: İzmir Örneği”. Cumhuriyet Üniversitesi Sosyal Bilimler Dergisi 30/1 (2006) 1-13.

Kolukırık S. \& Özcan N. (2019). "Farklılık ve Farkındalık Ekseninde Suriyeli Göçmen Nüfusun Sosyolojik Özellikleri: Payas İlçesi Örneği”. Göç Dergisi 6/2 (2019) 191-212.

Köse A. (2008). "Küreselleşme Çağında Bir Aidiyet Zemini ve Örgütlenme Şekli Olarak Hemşehrilik". Akademik Incelemeler Dergisi 3/1 (2008) 221-232.

Kurtoğlu A. (2005). "Mekansal Bir Olgu Olarak Hemşehrilik ve Bir Hemşehrilik Mekanı Olarak Dernekler". European Journal of Turkish Studies 2 - Hometown Organisations in Turkey, Kaynak: http://www.ejts.org/document375.html

Leech N. L. \& Onwuegbuzie A. J. (2009). "A Typology of Mixed Methods Research Designs". Quality and Quantity 43/2 (2009) 265-275 https://doi.org/10.1007/s11135-007-9105-3

Lefebvre H. (2014). Mekanın Üretimi. Çev. Işık Ergüden. İstanbul 2014.

Lordoğlu K. \& Aslan M. (2016). "En Fazla Suriyeli Göçmen Alan Beş Kentin Emek Piyasalarında Değişimi: 2011-2014". Çalışma ve Toplum Ekonomi ve Hukuk Dergisi 2 (2016) 789-808. 
Maani, S. A. (2016). "Ethnic Networks and Location Choice of Immigrants". IZA World of Labor (2016) 284 doi: 10.15185/izawol.284 Kaynak: http://insights.lewissilkin.com/articles/ethnic-networks-andlocation-choice-of-immigrants/long

Schönwälder K. \& Söhn J. (2009). "Immigrant Settlement Structures in Germany: General Patterns and Urban Levels of Concentration of Major Groups". Urban Studies 46/7 (2009) 1439-1460.

Südaş İ. (2005). Türkiye'ye Yönelik Göçler ve Türkiye'de Yaşayan Yabancılar: Alanya Örneği. Yayımlanmamış Yüksek Lisans Tezi, Ege Üniversitesi, İzmir 2005.

UNHCR (1997). UNHCR Comphrensive Policy on Urban Refugees. Geneva 25 Marc 1997, Kaynak: http://www.refworld.org/pdfid/41626fb64.pdf

Ünal S. (2012). "Sosyal-Mekansal-Siyasal Kümelenme Biçimi Olarak İzmir Kentinde Balkan (Rumeli) Kimliği”. Çă̆daş Yerel Yönetimler 21/3 (2012) 49-77.

Van Kempen R. \& Özüekren A. Ş. (1998). "Ethnic Segregation in Cities: New Forms and Explanations in a Dynamic World". Urban Studies 35/10 (1998) 1631-1656.

Wang X. \& Maani S. A. (2014a). "Ethnic Capital and Self-Employment: A Spatially Autoregressive Network Approach". IZA Journal of Migration 3/1 (2014a) 1-24.

Wang X. \& Maani S. A. (2014b). "Immigrants' Location Choices, Geographic Concentration, and Employment in New Zealand". New Zealand Population Review 40 (2014b) 85-110.

Yakar M. (2013). "Türkiye'de Yurtdışı Doğumlu Nüfusun Gelişimi ve Dağılışı”. Uluslararası İnsan Bilimleri Dergisi 10/1 (2013) 494-523.

Yakar M. \& Temurçin K. (2013). "Yurtdı̧ından Türkiye'ye Kim, Nereye Göç Ediyor?". Zeitschrift für die Welt der Türken 5/1 (2013) 217-231. 